\title{
Isolation of a Characteristic Phthiocerol Dimycocerosate from Mycobacterium leprae
}

\author{
By P. DRAPER ${ }^{1 *}$, SHEILA N. PAYNE ${ }^{1}$, G. DOBSON ${ }^{2}$ AND \\ D. E. MINNIKIN ${ }^{2}$ \\ ${ }^{1}$ National Institute for Medical Research, Mill Hill, London NW7 IAA, U.K, \\ ${ }^{2}$ Department of Organic Chemistry, The University, Newcastle upon Tyne NE1 7RU, U.K.
}

(Received 8 July 1982; revised 30 September 1982)

A characteristic mycobacterial wax, phthiocerol dimycocerosate, has been isolated from liver of armadillos experimentally infected with Mycobacterium leprae. The structure of this wax is generally similar to that produced by Mycobacterium tuberculosis, but the homologous phthiocerol and the mycocerosic acid components from $M$. leprae are significantly different from those of $M$. tuberculosis.

\section{INTRODUCTION}

Mycobacteria are capable of synthesizing a variety of complex lipids (Goren \& Brennan, 1979) whose distribution is of interest in classification and identification (Minnikin \& Goodfellow, 1980). A characteristic class of lipids consists of waxes composed of phthiocerol (I, $n=20,22$ ) esterified with multimethyl-branched long-chain acids (II, $x=3 ; n=14,16,19$ and $x=4 ; n=16,18,20$ ) for which the trivial names mycocerosic (Asselineau et al., 1959) or mycoceranic (Polgar \& Smith, 1963) acids are used. Phthiocerol dimycocerosate (PDIM) waxes were originally isolated from Mycobacterium tuberculosis (Noll, 1957) and are also possibly present in Mycobacterium bovis (Randall \& Smith, 1964; Koul \& Gastambide-Odier, 1977) and Mycobacterium marinum (Navalkar et al., 1965). Chromatographic evidence for the presence of these lipids in spleen of armadillos infected with Mycobacterium leprae and in human lepromatous tissues has been obtained by Young (1981). This communication confirms the presence of PDIM in infected armadillo tissues and reports that chemical degradation of the $M$. leprae-derived lipid yields mixtures of components that are significantly different from those obtained from phthiocerol dimycocerosate isolated from $M$. tuberculosis.

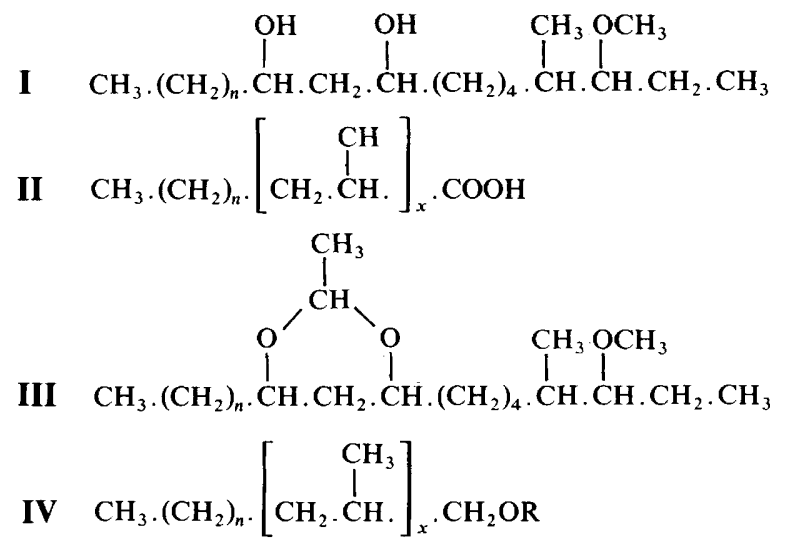

Abbreviations: PDIM, Phthiocerol dimycocerosate; TBDMS, $t$-butyldimethylchlorosilane. 


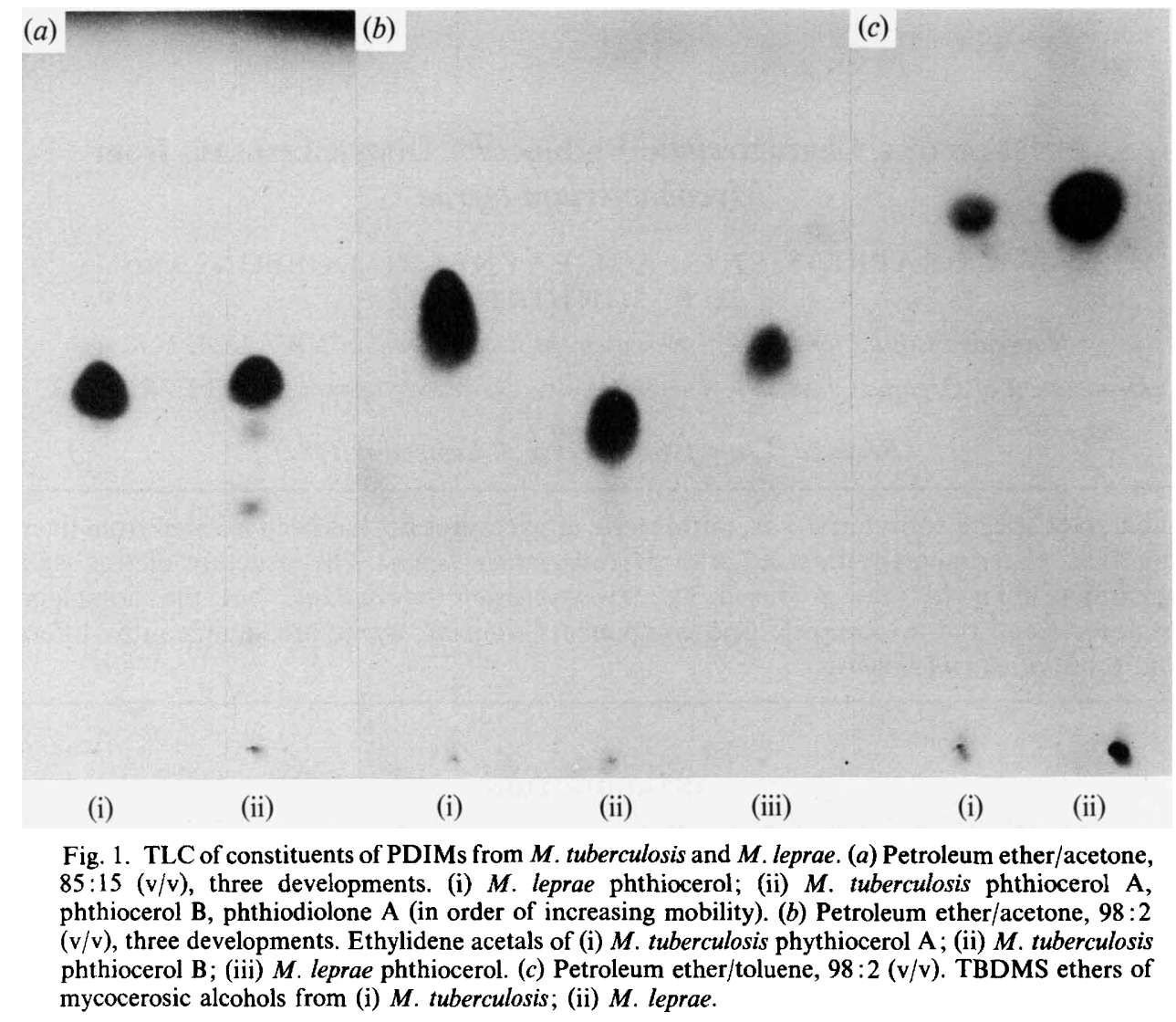

\section{METHODS}

PDIM was isolated from bacteria-free supernatants from homogenates of $M$. leprae-infected armadillo liver (World Health Organization, 1980) prepared as follows: tissues were homogenized in $0 \cdot 15 \mathrm{M}-\mathrm{NaCl} / 2 \mathrm{M}-\mathrm{Tr}$ ris base $(9: 1, \mathrm{v} / \mathrm{v})$ and centrifuged at $10000 \mathrm{~g}$ for $10 \mathrm{~min}$. The alkaline supernatant fluid was neutralized with $\mathrm{HCl}$ and reduced in volume $\left(40^{\circ} \mathrm{C}\right.$ in vacuo). Lipids were extracted by the procedure of Folch et al. (1957), using $\mathrm{KCl}$ in the aqueous phase to reduce accumulation of material at the interface $[0 \cdot 37 \%(\mathrm{w} / \mathrm{v}) \mathrm{KCl}$ used to form 2 phases; the same total concentration in the washing solvent]. The washed lower phase was filtered and evaporated to a thick oil.

A column of silica gel (Hopkin \& Williams MFC; 60-120 mesh) was prepared in light petroleum (b.p. 60$\left.80^{\circ} \mathrm{C}\right) /$ diethyl ether $(1: 1, \mathrm{v} / \mathrm{v})$. The oil was mixed with a slurry of a small amount of silica gel in the same solvent mixture and applied to the column. The solvent mixture was also used to develop the column. Fractions eluted were purified further by preparative TLC using Merck 7731 silica gel G plates and light petroleum/diethyl ether/acetic acid $\left(90: 8: 2\right.$, by vol.) as solvent to give a lipid $\left(R_{F} 0.95\right)$ co-chromatographing with authentic PDIM from $M$. tuberculosis (kindly provided by Dr Mayer B. Goren, National Jewish Hospital, Denver, Co., U.S.A.) A further sample of PDIM was isolated from $M$. tuberculosis strain C (from the Central Veterinary Laboratory, Weybridge).

Efficient reductive deacylation was achieved by stirring PDIM samples with $\mathrm{LiAlH}_{4}$ in dry diethyl ether for $2 \mathrm{~h}$ at room temperature. Separation of the ether layer, after sequential addition of ethyl acetate and water, gave phthiocerols and mycocerosic alcohols. Attempts to cleave PDIM under the following conditions gave minimal reaction $(<10 \%): 10 \%(\mathrm{w} / \mathrm{v}) \mathrm{KOH}$ in methanol/benzene $(1: 1, \mathrm{v} / \mathrm{v})$ for $48 \mathrm{~h}$ at room temperature (Koul \& Gastambide-Odier, 1977); methanol containing $5 \%(\mathrm{w} / \mathrm{v}) \mathrm{KOH}, 2 \%(\mathrm{v} / \mathrm{v})$ water and $20 \%(\mathrm{v} / \mathrm{v})$ benzene under reflux for $3 \mathrm{~h}$ (Asselineau et al., 1981); methanol/toluene/ $\mathrm{H}_{2} \mathrm{SO}_{4}\left(30: 15: 1\right.$, by vol.) at $75^{\circ} \mathrm{C}$ for $16 \mathrm{~h}$ (Minnikin et al., 1980); $0.25 \mathrm{M}$-sodium methoxide in $\mathrm{CHCl}_{3} /$ methanol $(1: 1, \mathrm{v} / \mathrm{v})$ at $20^{\circ} \mathrm{C}$ for $1 \mathrm{~h}$.

Phthiocerols (I) $(<5 \mathrm{mg})$ were converted to ethylidene acetals (III) by reaction at room temperature overnight with acetaldehyde $(0.5 \mathrm{ml})$ in toluene $(1 \mathrm{ml})$ containing a crystal of toluene-4-sulphonic acid (Minnikin \& Polgar, 1966). Mycocerosic alcohols (IV, $\mathrm{R}=\mathrm{H} ;<5 \mathrm{mg}$ ) were reacted at $75^{\circ} \mathrm{C}$ overnight with TBDMS/imidazole/di- 
(a)

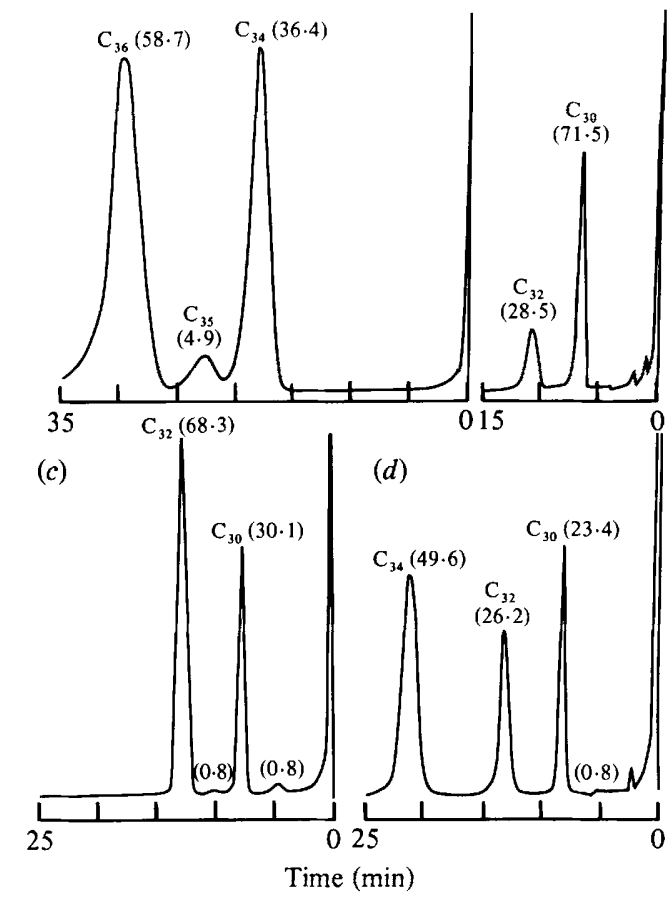

Fig. 2. Gas chromatography of constituents of PDIMs from $M$. tuberculosis and $M$. leprae using a $1 \mathrm{~m}$ $2.5 \% \mathrm{OV}-1$ column isothermally at $280^{\circ} \mathrm{C}$. Values in brackets represent percentages of the total mixture and numbers of carbons (e.g. $\left.\mathrm{C}_{36}\right)$ are those assigned to the underivatized parent molecules. $(a, b)$ Ethylidene acetals of $M$. tuberculosis phthiocerol A and $M$. leprae phthiocerol. $(c, d)$ TBDMS ethers of mycocerosic alcohols from $M$. tuberculosis and $M$. leprae.

methylformamide reagent $(0.15 \mathrm{ml})$ as previously described (Minnikin \& Patel. 1979). Analytical TLC of PDIM reduction products and their derivatives was performed using aluminium-backed silica gel sheet (Merck 5554); preparative TLC used $1 \mathrm{~mm}$ layers of Merck 7784 silica gel $\mathrm{PF}_{254+366}$. Gas chromatography was performed with a Perkin-Elmer F11 flame-ionization instrument fitted with a stainless steel column $(1 \mathrm{~m} \times 2 \mathrm{~mm}$ i.d. $)$ packed with $2.5 \%$ OV-1 methyl silicone on 80-100 mesh Chromosorb G AW-DMCS at $280^{\circ} \mathrm{C}$, with nitrogen as a carrier gas. Mass spectrometry was carried out using an A.E.I. MS9 instrument.

\section{RESULTS AND DISCUSSION}

The phthiocerol fraction from $M$. leprae was compared by TLC (Fig. 1a) with a standard sample from $M$. tuberculosis containing phthiocerol A, phthiocerol B and phthiodiolone A (Minnikin \& Polgar, 1966). The similar mobility of the $M$. leprae phthiocerol to that of phthiocerol A suggested that both were methoxy diols having the general structure (I); phthiodiolone A (Minnikin \& Polgar, 1967) has a keto group in place of the methoxy function and phthiocerol B has a terminal- $\mathrm{CH}\left(\mathrm{OCH}_{3}\right) \cdot \mathrm{CH}_{3}$ unit (Minnikin \& Polgar, 1966). This result was supported by conversion of the $M$. leprae phthiocerol to its ethylidene acetal (III) and comparison of this derivative (Fig. $1 b$ ) with similar derivatives from $M$. tuberculosis by TLC.

The only other long-chain components formed on reduction of $M$. leprae PDIM cochromatographed $\left(R_{F} \mathbf{0 . 5 9}\right)$ on TLC plates [solvent light petroleum/acetone, $95: 5(\mathrm{v} / \mathrm{v})$, three developments] with mycocerosic alcohols (IV, $\mathrm{R}=\mathrm{H}$ ) prepared from PDIM isolated from $M$. tuberculosis. After conversion of these alcohols to TBDMS ethers [IV, $\left.\mathrm{R}=\mathrm{Si}\left(\mathrm{CH}_{3}\right)_{2} . \mathrm{C}\left(\mathrm{CH}_{3}\right)_{3}\right]$ their chromatographic mobility $\left(R_{F} 0.64\right)$ was again identical (Fig. $1 c$ ); derivatives of hexadecanol and elaidic alcohol had $R_{F}$ values of 0.36 and 0.26 , respectively. It is thus apparent that the fatty acid components of $M$. leprae PDIM are closely related to mycocerosic acids.

The results of gas chromatography of the ethylidene acetals of the phthiocerols and the 
TBDMS ethers of the mycocerosic alcohols from both sources are shown in Fig. 2. It appears that the PDIM from $M$. leprae contains novel 30 and 32 carbon homologues of phthiocerol $A$. Mass spectrometry of the TBDMS ethers of the mycocerosic alcohol mixture from $M$. tuberculosis showed a peak at $m / e 513(\mathrm{M}-57$, Minnikin \& Patel, 1979) corresponding to a main 32 carbon component (IV, $x=4, n=18$ ). The gas chromatographic data (Fig. 2) suggest that the mycocerosates of $M$. leprae PDIM are composed of a homologous 30,32 and 34-carbon series (II, $x=4, n=16,18,20$ ), the latter being the main component.

The isolation from $M$. leprae of a characteristic PDIM wax with phthiocerol and mycocerosic acid components having a distinctive composition is of value in the classification of this pathogen. Taxonomic markers have been hard to find for $M$. leprae, mainly because it has not so far been grown on any bacteriological medium. Mycobacterium leprae also produces a phenolphthiocerol-based mycoside (Hunter \& Brennan, 1981); this type of lipid has been found previously only in representative strains of $M$. bovis, $M$. kansasii and $M$. marinum (Goren \& Brennan, 1979; Minnikin \& Goodfellow, 1980). The presence of these two very characteristic mycobacterial lipids in $M$. leprae reinforces the idea that it is related to other mycobacteria, rather than more closely to corynebacteria as suggested by recent studies on nucleic acid composition (Imaeda et al., 1982).

Thanks are due to the IMMLEP Steering Committee of the UNDP/World Bank/WHO Special Programme for Research and Training in Tropical Diseases for provision of infected armadillo tissue and a grant (T16/181/L4/29). G. Dobson is the recipient of a studentship from the British Leprosy Relief Association. Mass spectra were recorded by P. Kelly and S. H. Addison. Thanks are due to Dr R. H. Gigg for advice, and Dr M. B. Goren for advice and provision of a sample of PDIM.

\section{REFERENCES}

Asselineau, C., Asselineau, J., Ryhage, R., StällBerG-STENHAGEN, S. \& Stenhagen, E. (1959). Synthesis of (-)-methyl 2D,4D,6D-trimethylnonacosanoate and identification of $\mathrm{C}_{32}$-mycocerosic acid as a 2,4,6,8-tetramethyloctacosanoic acid. Acta chemica scandinavica 13, 822-824.

Asselineau, C., Clavel, S., Clément, F., Daffé, M., David, H., Lanéelle, M. A. \& Promé, J. C. (1981). Constituants lipidiques de Mycobacterium leprae isolé de tatou infecté expérimentalement. Annales de Microbiologie 132A, 19-30.

Folch, J., Lees, M. \& Stanley, G. H. S. (1957). A simple method for the isolation and purification of total lipids from animal tissues. Journal of Biological Chemistry 226, 497-509.

Goren, M. B. \& BRENNAN, P. J. (1979). Mycobacterial lipids: chemistry and biologic activities. In Tuberculosis, pp. 63-193. Edited by G. P. Youmans. Philadelphia: W. B. Saunders.

Hunter, S. W. \& Brennan, P. J. (1981). A novel phenolic glycolipid from Mycobacterium leprae, possibly involved in immunogenicity and pathogenicity. Journal of Bacteriology 147, 728-735.

ImAeDA, T., KirchHeimer, W. F. \& Barksdale, L. (1982). DNA isolated from Mycobacterium leprae: genome size, base ratio, and homology with other related bacteria as determined by optical DNADNA reassociation. Journal of Bacteriology 150, 414 417.

Koul, A. K. \& Gastambide-Odier, M. (1977). Microanalyse rapide de dimycocérosate de phthiocérol, de mycosides et de glycérides dans les extraits à l'éther de petrole de Mycobacterium kansasii et du BGG, souche Pasteur. Biochimie 59, 535-538.

MinNikin, D. E. \& Goodfellow, M. (1980). Lipid composition in the classification and identification of acid-fast bacteria. In Microbiological Classification and Identification, pp. 189-256. Edited by $\mathbf{M}$. Goodfellow and R. G. Board. London: Academic Press.

Minnikin, D. E. \& Patel, D. V. (1979). Butyldimethylsilyl ethers of iodine-catalysed solvolysis products of long-chain epoxides. Chemistry and Physics of Lipids 23, 173-178.

Minnikin, D. E. \& Polgar, N. (1966). Studies relating to phthiocerol. Part V. Phthiocerol A and B. Journal of the Chemical Society $(C), 2107-2112$.

Minnikin, D. E. \& Polgar, N. (1967). Studies relating to phthiocerol. Part VII. Phthiodiolone A. Journal of the Chemical Society $(C), 803-807$.

Minnikin, D. E., Hutchinson, I. G. \& Caldicott, A. B. (1980). Thin-layer chromatography of methanolysates of mycolic acid-containing bacteria. Journal of Chromatography 188, 221-233.

Navalkar, R. G., Wiegeshaus, E., Kondo, E., Kim, H. K. \& SMITH, D. W. (1965). Mycoside G, a specific glycolipid in Mycobacterium marinum (balnei). Journal of Bacteriology 90, 262-265.

NolL, H. (1957). The chemistry of some native constituents of the purified wax of Mycobacterium tuberculosis. Journal of Biological Chemistry 224, 149164.

Polgar, N. \& Smith, W. (1963). Mycoceranic acid. Part III. Journal of the Chemical Society, 30813085.

RANDALl, H. M. \& SMITH, D. W. (1964). Characterization of mycobacteria by infrared spectroscopic examination of their lipid fractions. Zentralblatt für Bakteriologie, Parasitenkunde, Infektionskrankheiten und Hygiene. (I. Abteilung) 194, 190-201. 
WORLD HEALTH ORGanization (1980). UNDP/World Bank/WHO Special Programme for Research and Training in Tropical Diseases. Report of the Fifth Meeting of the Scientific Working Group on the Immunology of Leprosy (IMMLEP). TDR/IMM-
LEP-SWG(5)/80.3, Annex 4, p. 23, Geneva: World Health Organization.

YouNG, D. B. (1981). Detection of mycobacteriol lipids in skin biopsies from leprosy patients. International Journal of Leprosy 49, 198-204. 